\title{
Black Poetry in South Africa: Its Origin and Dimension
}

Is there anything like black poetry in South Africa, as divorced from Jewish poetry, Afrikaans poetry, and English poetry? Are there ethnic poetry differences in our society? My answer to that is a big "yes."

I give an affirmative answer because a black man's life in South Africa is an endless series of poems of humor, bitterness, hatred, love, hope, despair, and death. His is a poetic existence shaped by the harsh realities and euphoric fantasies that surround him.

Every day is a challenge in survival not only in the physical sense but also spiritually, mentally, and otherwise. It is hard for people who live in "free societies" to comprehend a black man's life in this strange society. If you do not share my environment and my culture it is hard to understand what I am talking about.

I can only explain this life that generates and inspires black poetry by making an example of a typical black child's life from birth to death. Perhaps this illustration will clarify what I mean.

Jabulani Moya was born at Baragwanath Hospital in Johannesburg. His parents live at Zola Township, where they occupy a four-room house. Jabulani has to get a birth certificate from the hospital which is issued through the Bantu Commissioner. This certificate must be presented to the township superintendent who then authorizes Jabulani to legally join his parents when his name is put on the house permit. If the parents fail to follow this onerous procedure, it does not augur well for Jabulani's entrance into this world.

When Jabulani reaches school age, he registers in an ethnic school for Zulus because that is what his parents are. His schoolmates and playmates are supposed to be Zulus. Jabulani will be taught in Zulu by Zulu teachers until standard 3. If he does not drop out before then, he can continue his education in English and Afrikaans.

After going through high school, he will enroll in a Zulu university, where he will come into more direct contact for the first time with white people. Like the township superintendent, the university authorities wield enormous power over the life of Jabulani. And when he graduates he will take a job that is tailored only for his qualifications as a black man. He comes into more contact with a white man, who is his employer. 
When he has saved enough money he will marry a Zulu girl, who also must have been born in Johannesburg. If he fancies a girl from Springs or Pretoria he must forget her, because they will not be allotted a house in Soweto. His life is restricted to Soweto and he must only work in Johannesburg. Even if he is offered a more remunerative job, say in Bloemfontein, he cannot take it. When he dies he will be buried at Doornkop Cemetery, where other Soweto residents are buried.

In this brief outline I have sketched the life of Jabulani Moya, but if we gave him a pen and paper and asked him to write about himself and his experiences, what would we get? Black experience.

If an artist is shaped by his environment and society, then Jabulani Moya would be no exception. I am using the word "artist" in its broadest sense. What Jabulani would produce would be black art.

Black art, of course, has its different fields like visual arts, drama, music, and literature. If Jabulani Moya is a poet, then his poetry will depict his life and the people around him. It will describe stokvels, shebeens, police vans, prisons, churches, hospitals, trains, murders, rapes, robberies, night vigils, and funerals-in short, all aspects of a black man's life.

If a black artist uses his paint and brush or pen and paper to depict these scenarios of his life, his work is given the name of "township art" by the white critics. I cannot go into the merits and demerits of that tag which has been attached to our works, except to say that to me it smacks of patronizing, if not downright contempt.

It is for that reason that I will restrict myself to what I believe is black poetry or township poetry if anyone wants to call it that. As I have said before, black poetry depicts the black man's life as it is shaped by the laws that govern him. He has no hand in the making of these laws, but he must abide by them. Black poetry is the mirror that reflects black man's aspirations, his hopes and disappointments, his joys and sorrows, his loves and hates.

A poet, or for that matter any artist, cannot contrive his subject matter or themes. He must know what he is writing about. If he does not, he will come up with something unnatural, unrealistic, and downright phony. Only a Jewish poet can write about bar mitzvah. Only an Afrikaaner poet can describe Nagmaal.

I, as a black man, can tell you how I slaughter a black goat for my ancestors. The rest is as remote and foreign to me as the changing of the Queen's Guards at Buckingham Palace.

Poetry is the language of emotions. Only words can convey the meaning of this language to the heart, wher emotions are said to be situated. These emotions are only existent in human beings, with the result that creatures other than Homo sapiens are said to be devoid of love, hate, fear, despair, and hope. Consequently, every person should, because he has emotions, 
understand and appreciate poetry; otherwise he is no different from a brute or a stone.

Like people all over the world, we black people of South Africa have emotions. We love, we hate, we fear, we despair, we aspire. I do not exaggerate if I say to a certain extent we do these things to a higher degree than other people. For instance, we have hope in our hearts which through centuries has come to cease to be a virtue and has turned into a vice, the reason being simply that we seem to have been hoping against hope. Whether this has had a stultifying effect on our other emotions and feelings is very difficult to say.

In recent times, within the past few years to be exact, our feelings as black people have become more and more vocal. For too long we have been muffled by our unfounded fears which we cannot contain any more. Of course there have been real fears of being lynched, murdered, and imprisoned if we dared to raise our voices to what we knew for a long time to be wrong and expected to be righted. Our fears have been compounded by the teachings of missionaries about heaven and hell. Acceptance of the injustices perpetrated on our lives would be rewarded with heavenly bliss, and the opposition of this oppression would lead to perdition; so we were taught to believe. Of course now we have seen through this smokescreen and we know the truth.

Before I elaborate on the poetry movement among the black people in South Africa, I want to describe and analyze the racial setup in my country, which is South Africa. I want to do this so that, I hope, you will get a clearer picture of my position and that of my fellow black men.

At the last census taken in 1971 there were about 21 million people living in South Africa: about sixteen million Africans like me, then three million whites, a million and a half coloreds or mulattoes, and less than a million people of Indian descent. We Africans have lived in southern Africa since time immemorial, that is, according to our indisputable black historical facts; the alternative explanation, namely that we came to South Africa from the Equator at the same time as the Honorable Mr. Jan van Riebeeck in 1652 , is nothing else but fiction.

I have been fortunate enough to have been taken, by a friend of the family before she died, on a tour to a row of caves in the Lebombo Mountains in the northern part of Zululand. That guide was an old woman of about ninety or more and I was about ten years old then. She told us (my oldest brother was there too) that the caves were there when she grew up. They were used as hiding places during the wars and endless battles that were fought between Zulus and Swazis, and also during the wars that followed later between whites and Zulus. Some of the dwellers in those caves were my ancestors who fled Shaka's wrath and vengeance after he and his army invaded Ntabankulu (Big Mountain), the ancestral home of the Mtshali 
clan. Later on some of my forebears settled in Northern Zululand and Swaziland.

Though I was quite young when I was told this exciting bit of my history, I still remember it as vividly as if the old crone had related it to me last night. I remember seeing the timeless relics of my past, like clay pots, crude iron tools and a kiln where iron was smelted to forge assegais (imikhonto), battle axes (izizenze), hatchets (ocelemba), and of course hoes (amageja) for tilling the soil. As could be expected, archeologists and excavators have discovered some of these caves which stand in a somewhat long row from the village of Ngotshe (Louwsburg) and Magudu to the Lebombo Mountain side of Swaziland.

I have digressed from the topic of black poetry in South Africa. I have given you the background to my culture which will provide you with an insight into my timeless existence and civilization in southern Africa before the advent of the so-called refined and much-vaunted western civilization.

Our existence having been established beyond any doubt, I wish to propound the fact that we had and in some parts of the country still have the remnants of a beautiful culture, which makes my heart bleed when I see it raped, prostituted, and destroyed since the first contact the black man has had with the followers of Jan van Riebeeck. Wherever I go I try to collect the debris of my shattered culture and try to immortalize it in my poetry. That is why I have now more than before let the muse dictate to me in English and Zulu. I write in English for my present state of reality or unreality and I write in Zulu to establish my identity which will be translated by posterity. Only then will my past heritage be accorded its right and respectful position. For me that will be absolute and the most highly cherished freedom anyone can endow me with.

The greatest tragedy that ever befell the black man in the southern part of Africa is not that he did not invent the wheel, but that he could not write. Otherwise, if he could, I would be reading to you today poetry that was written long before the birth of Jesus Christ. I call this a tragedy because this inability to record our civilization has contributed to the gross misrepresentation of our culture as far as the written word is concerned; but the redeeming factor, for which the black is eternally grateful, is the preservation of the paintings of the Abathwa people in mountain caves in some parts of southern Africa. We are also grateful to the black sculptors who recorded our culture through their works which are found all over the continent of Africa. But the most important contributors and preservers of our civilization are the musicians whose musical instruments are in great evidence in many parts of Africa. The songs, though passed from mouth to mouth and not scored, are as fresh as ever. I am thinking of the war songs and the war cries of my people, the Zulus. My grandmother used to sing them to me 
as freshly as her grandmother used to sing them to her. Hence from what she told me I could learn what an artist like a poet could and should do for society.

The role that can be played by a singer or a poet is a great one indeed. To us, black people of South Africa, Miriam Makeba is a goddess of our struggle to be free because she has articulated our feelings and immortalized our wretched lives, thus proclaiming that every black man wants freedom in the land of his birth. This is an obligation I have taken upon myself to carry out, in my own modest way through my poetry, for the liberation of my people.

I have purposely not dwelt on the political side of my country because this is too well known for me to mention. I have only mentioned the results of the contact with the white man since 1652 which, with dire consequences, has denuded the black man of his dignity because of the destruction of his civilization and culture. As I have said, through my poetry I am trying to gather the scattered pieces of my culture, and this is not my goal only; it is also that of the crop of other poets who have sprung up like mushrooms in the stormy life of the black man. It is dictated by the political ideology pursued by the government of South Africa. This political policy is known to the outside world under the insidious name of apartheid. In South Africa it is respectfully called Separate and Equal Development.

One may ask then what has poetry to do with this political setup that separates the black man from the white, and is imposed on a voteless black majority by a white electorate. The answer is that black poetry like every art form describes and depicts the life of the black people in this society. It portrays the lives of the people who find themselves helpless victims in vicious circumstances not of their own making. The black poets who have sprung from seemingly nowhere are the oases in the bleak desert of the black man's life, from which he will drink the waters of liberation as he forges his way to the green pastures of complete freedom. The poetry of twenty years ago is far less strident in its feeling than that of the present. The reason is that the political events in the African continent have given the situation in South Africa a sense of urgency. This momentum is rising to a feverish pitch from both sides, the white man's side and the black man's side. In this dramatic stage of our development I find that to keep pace with the latest events one needs a very objective mind. A few weeks ago, I attended a memorial service in Soweto for Mr. Abram Ongkopoetse Tiro, a twenty-seven-year-old black leader who was killed by a parcel bomb in Botswana, where he was living in exile from South Africa. A very large crowd of black people, young and old, attended this church service. And one of the most remarkable sights to observe was the lack of emotionalism and hysterics, which are very common in our funerals. Instead there was a 
calm and a grim determination to continue where Mr. Tiro had left off. Indeed, if ever there were people who knew their destiny, those were the people.

Another contributory factor to the urgency and potency of the black poetry movement is the increase in the number and the harshness of the laws that govern the black man. This has been brought about by the impetus of the ever-increasing strikes by the Zulu workers around Durban and the events which are happening beyond the borders of our country. Thus one can see that the poems of Bloke Modisane and Can Themba in the early fifties were more subtle and humorous than those of the current poets like Mongane Serote and James Matthews, whose poetry is the reflection of ever-growing and fast proliferating black awareness, black consciousness, and its end result, black power. This spirit of self-assertion has been purposely made to appear sinister by the white press, even by our so-called liberal press, because the white people are horrified that the black men, that is the African, the colored, and the Indian, are coming together to form a single united block that will confront and demand freedom from white domination. The classic example of what I mean is the banning of Cry Rage, a book of poems written by James Matthews and Gladys Thomas, two beautiful black people I love. There was no outcry when this book was banned, there were no petitions signed by the white intelligentsia, there were no vociferous shoutings by the lily-white liberal press, and no fund was established to help the proscribed writers take the matter to court. The book was, I suppose, justifiably banned for being black power propaganda. But a few weeks ago an Afrikaaner writer had his work banned, the first time in the history of white literature that a thing like this ever happened, and the noise that has followed has deafened the whole world. I will not be surprised if it has reached your ears as well. I, as a black man, am not surprised by the duplicity that every black man has come to expect from the whites. It is these double standards practiced by the whites that the black poets are questioning, condemning, and rejecting as pernicious and retarding to the black man's struggle.

You may wonder why there is this upsurge of black poetry in South Africa. I have given part of an answer at the beginning of the talk. And I have explained the emotional strings played by poetry in the black man's heart. Other forms of writing will follow just as night follows day. In fact two plays are a pointer to this direction. These plays are nothing else but a mirror of a black man's life in the present situation. They tell how a black man finds himself caught up in the cobweb of the multifarious laws that govern him, especially the much-detested pass laws that restrict every black man.

In the near future I do not foresee any novelist coming out of South Africa because the urgency of the situation does not allow time to sit down 
and pen a lengthy piece of writing, as demanded by a novel. Another factor against a novel is that poetry, music, and drama can be shared with many other people at the same time. But a novel can only be read alone. I suppose it's the black man's gregarious instinct to share the bitter and the sweet, or as one black sage once said, "A sorrow shared is a sorrow lessened, and a joy shared is a joy increased a hundredfold."

Now why do black poets in South Africa write in English if they are proud of their culture? I will quickly point out that I write in English and Zulu, as I have said before. But the answer to this question I have given already. I will only amplify it by saying that the English that we use in our poetry is not the Queen's language that you know as written by, say, Wordsworth and Coleridge. It is the language of urgency which we use because we have an urgent message to deliver to any one who cares to listen to it. We have not got the time to embellish this urgent message with unnecessary and cumbersome ornaments like rhyme, iambic pentameter, abstract figures of speech, and an ornate and lofty style. We will indulge in these luxuries which we can ill afford at the moment when we are free people. Only then shall we write about bees, birds, and flowers. Not the harsh realities that are part and parcel of black man's life.

PAI HSIEN-YUNG / TAIWAN

\section{The Wandering Chinese:} The Theme of Exile in Taiwan Fiction

Traditionally during Chinese history, when severe social and political dislocations occurred, those intellectuals who wished to maintain their integrity often chose to retreat from society either as a gesture of protest or simply for the practical reason of survival. These exiles sought consolation in nature and philosophy, while finding their personal expression in art and literature. Their artistic creations, whose merits were rarely recognized at the time, would nevertheless become important testaments for posterity.

With the defeat of the Nationalists on the mainland in 1949, China once again witnessed a period of social and political upheaval whose magnitude is still too awesome for us to fathom. This cultural cataclysm could not fail to impinge upon the imagination of those writers whose works bear 